International Journal of Instruction e-ISSN: 1308-1470 • www.e-iji.net
October $2020 \bullet$ Vol.13, No.4

p-ISSN: 1694-609X

pp. $747-762$

Received: 21/10/2019

Revision: 11/05/2020

Accepted: 01/06/2020

OnlineFirst:22/08/2020

\title{
Development of Multi-representation Based Electronic Book on Inter Molecular Forces (IMFs) Concept for Prospective Chemistry Teachers
}

\section{Rahmat Rasmawan}

Faculty of Teacher Training and Education, Tanjungpura University, Indonesia, rahmatfkip@gmail.com

The purpose of this research was to develop a multi-representation based e-book on the concept of intermolecular forces that is valid and feasible for use. The form of research used was Research and Development (R\&D), which refers to the ADDIE development model consisting of five stages, namely analysis, design, development, implementation and evaluation. Data collection tools at the analysis stage were broken down to interview guidelines and observation sheets. At the development stage, the data collection tools used were content validation sheets (Content Validity) and views (Face Validity). At the implementation stage, the data collection tool utilized was an test of understanding on the concept of intermolecular forces. The results of content validation indicated that the developed e-book was valid. The face validity results showed that the correspondents were in agreement that the e-book had writing style and fonts that were easy to read, material explanations and videos that were easy to understand and images that were corresponding to the contents of the material. Overall, the ebook was found to be easily utilised and the material related to daily life. The ebook obtained learning outcomes that were to be highly mastered by the students.

Keywords: development, IMFs, electronic books, multi-representation, teachers

\section{INTRODUCTION}

The concept of chemistry is widely defined as the explanation of an occurrence of a natural phenomenon based on experimental results (Philip et al., 2014). The explanation of chemical phenomena is presented in various methods of representation which includes the occurrence of phenomena that are directly observable or macroscopically, microscopic explanation of the phenomenon and symbolised (Guzel \& Adadan, 2013; Siew Li \& Arshad, 2014; Harst \& Savec, 2017). Chemical concepts can be formed when they can connect chemical phenomena with microscopic visualisations or images (Yayla $\&$ Eyceyurt, 2011). Thus, the concept of chemistry can be understood in its entirety if it can relate macroscopic, microscopic and symbolic aspects; this is referred to as multirepresentation.

Citation: Rasmawan, R. (2020). Development of Multi-representation Based Electronic Book on Inter Molecular Forces (IMFs) Concept for Prospective Chemistry Teachers. International Journal of Instruction, 13(4), 747-762. https://doi.org/10.29333/iji.2020.13446a 
Intermolecular forces (IMFs) are one of the concepts in chemistry that require linking skills between aspects of multi-representation. Macroscopic representations of IMFs are related to the form of substances in liquid or solid form, symbolic representations are related to the chemical formula of the constituent particles and microscopic representations are related to interactions that occur between the constituent particles of substances. In addition, IMFs are the basis for learning other chemical concepts. Hence, if students fail to master it, they may be inhibited from learning other chemical concepts (Lawrie et al., 2013). For example, the concept of IMFs is used in predicting the solubility of a substance based on the principle of "like dissolved like" and the boiling point of organic compounds (Rantih et al., 2019).

The facts show that most students fail to link macroscopic, microscopic and symbolic aspects in IMFs. Students have the correct understanding of the definition of hydrogen bonds and the dipole-dipole force but fail to describe the process of the formation of forces between molecules microscopically or at the molecular level (Cooper et al., 2015). Students also fail to predict the types of IMFs that occur based on their molecular structure. Also, students can predict the solubility of ion compounds with polar solvents but fail to describe the dissociation process (Malkoc, 2017). It was also found that the students can write the chemical formula of the constituent particles of matter but failed to describe the process of interaction between these particles (Musawwa et al., 2018). There is still an assumption that IMFs of hydrogen bonds are a force that arise from bonds between $\mathrm{O}$ and $\mathrm{H}$ atoms in one molecule, not between molecules (Schmidt et al., 2009; Widarti et al., 2019).

The main reason for the lack of skills in linking the relationship between aspects of multi-representation is due to the lack of the availability of books that emphasise macroscopic and symbolic aspects rather than microscopic aspects (Pande \& Chandrasekharan, 2017; Al-Balushi, 2013; Aydin et al., 2014; Gkitzia et al., 2011; Demirdogen, 2017). Rantih, et al. (2019) analysed five textbooks discussing IMFs. The results obtained were that the five books explained the concept of the IMFs clearly but three of the five books emphasised the macroscopic and symbolic aspects rather than the microscopic aspects. There was also the tendency to explain microscopic aspects in the form of explanatory words that could lead to misinterpretation. The impact arising from the use of these textbook could lead to the assumption that chemistry is abstract and can form misconceptions (Sunyono, 2015; Parpageorgiou et al., 2016; Zang \& Linn, 2011).

Considering the importance of understanding the concept of IMFs, multi-representation based textbooks are needed. These textbooks would make it easy for prospective chemistry teachers and students to gain a complete understanding of both macroscopic, microscopic and symbolic aspects - using the FlipPDFProEdition software. The practicality of the software can include text, images, audio, and dynamic visualisation in the form of video or animation and internet site links so that it enriches the type of book display (Linda et al., 2018). The advantages of dynamic visualisation that exist in ebooks have an impact on a complete understanding of the concepts being studied because dynamic visualisation can provide an expository display, describe the process of movement directly and appear relevant to actual reality (Hwang et al., 2012; Kumar et al., 2016; Bhatti et al., 2017; Rusli et al., 2017). Thus, the purpose of this research is 
to develop a multi-representation based e-book using FlipPDFProEdition software by integrating images, text, and dynamic visualisation. Through this e-book, it is hoped that prospective teachers and students can gain independent learning and a complete understanding of the concepts of IMFs and their relationship to macroscopic, microscopic and symbolic aspects.

Several studies have shown the effectiveness of using e-books in learning. Ebied \& Rahman (2015) found that students who were taught using e-books were better at achieving learning outcomes than using printed books, with an effect size of 0.43 in the medium category. Yasa et al. (2018) has developed an e-module by combining text, audio, animation, photos or images and sounds with different combinations of elementary school thematic learning and the results obtained showed that students are more motivated to learn and their learning achievements improved. Raihan et al. (2018) also developed e-books by integrating text, images, audio, video and animation which allows students to understand the material correctly. Biranvand \& Khasseh (2014) observed that using e-books caused significant improvements in academic ability, variety, flexibility and effectiveness in learning compared to students who learned using printed books.

\section{LITERATURE REVIEW}

The concept of IMFs is a basic concept that must be mastered because its application is quite extensive in studying other aspects of chemistry. The concept of IMFs is used in explaining the physical properties of compounds such as boiling points, freezing points, and solubility of inorganic and organic compounds (Schmidt et al., 2009; Cooper et al., 2015). The concept of IMFs is strongly influenced by the structure of the molecule, more specifically whether the molecule is polar or nonpolar. The dipole-dipole force will be formed for polar molecules that interact with the same or different polar molecules. Nonpolar molecules interact with the same or different nonpolar molecules so that the London force will form. Nonpolar molecules that interact with polar molecules will form induced dipole-dipole forces. Polar molecules that interact with ions will form the ion-dipole force. Nonpolar molecules that interact with polar or ion molecules will form an induced ion / dipole-dipole force.

Understanding the concept of IMFs must be done from various aspects of representation. This can be achieved by translating macroscopic aspects into microscopic and symbolic aspects or vice versa (Guzel \& Adadan, 2013). Macroscopic aspects of IMFs can be observed in several chemical phenomena that can be observed by the plain eye such as the form of substances, boiling points, the ability to intervene between two kinds of liquid and the solubility of solids in solution (Cooper et al., 2015). The symbolic aspect in IMFs is the symbol of the molecular composition of substances, molecular polarity and molecular movements which are usually marked with arrows and dashed lines (Rantih et al., 2019). Microscopic aspects in IMFs are related to the description of the process of interaction between particles of matter at the molecular level (Barbosa et al., 2015).

Learning the concepts of IMFs can be done by giving the right attention and material porportion between the three aspects of multi-representation. This was done by adding 
visualisations that can explain the events that appear macroscopically and symbolically to the molecular or microscopic level (Tasker \& Dalton, 2006; Skamp, 2009; Sunyono et al., 2017). Research by Scalco et al. (2018) shows results that students who are given visualisation images along with explanatory texts can explain a phenomenon in more detail and clearer than students who are only given visualisation in images or just text. Barbosa et al. (2015) developed an IMF concept software that combines phenomena, short text descriptions, molecular images and is equipped with video and animation to make it easier for users to understand and this can help independent learning.

\section{METHOD}

\section{Research Design}

The purpose of this study was to develop a multi-representation based e-book on IMFs concepts through the research design of Research and Development (R\&D). From this research, there was a valid and legitimate e-book developed that would be able to assist the students in understanding the concepts of IMF.

\section{Development Procedure}

The development step referred to ADDIE development model (Branch, 2009). The steps for developing were made up of analyse, design, development, implementation and evaluation.

\section{Analyze}

At this stage, an analysis of the potential problems that exist in learning chemistry between IMFs concepts was done. Potential analysis was carried out to assess the expectations and goals of teaching the concept of IMFs. The analysis of the problems was then carried out, namely the constraints and obstacles encountered in learning the concept of IMFs that hinder the achievement of goals. Constraints and obstacles were known from observations and interviews with lecturers and students.

\section{Design}

At this stage, an analysis was conducted to determine the learning outcomes of the IMFs material, concept or content limitation and indicators that would be achieved. This stage also searched for sources or materials to be used in developing electronic books such as reference books, animation, video and sound related to the IMFs concept.

\section{Develop}

At this stage, a draft of a multi-representation based e-book on the concept of intermolecular forces was produced. After the draft was produced, the next step was to validate it. Validation consists of two forms, namely content validation and face validity. Content validity was done by asking seven experts to assess the validity of the e-book that was developed. Face validity was done by asking 30 students who have studied the concept of IMFs to provide responses to the e-books developed.

\section{Implementation}

The product implementation was conducted by applying it to a basic chemistry course on IMF material. The population in the implementation stage was made up of students from the Chemistry Education Study Program consisting of three classes. One class was 
then chosen to be the subject of implementation. The consideration of subject selection was based on the first-year college students that take the class and who have not received IMFs material. From three classes, the Regular Class A-1 that consists of 27 students was chosen.

\section{Evaluation}

At this stage, there was an evaluation of the results from the implementation stage of the draft e-book on the IMF concept. The main focus at the evaluation stage was to determine the obstacles that appeared during the application of the developed draft electronic teaching material. The next step revised the electronic teaching material on the concept of IMFs based on a final multi-representation.

\section{Data Collection Tools}

In the analysing stage, the data collection tools used were interview guidelines and observation sheets. The interview guidelines were conducted to find out the obstacles faced by lecturers and students in learning IMFs concepts. Observation sheets were used to observe the learning implementation in a basic chemistry course especially in regards to material on IMFs. From the results of the interviews and observations, the problems that appeared in basic chemistry lectures especially on IMFs concept were determined. At the development stage, the conducted data collection tools were content validity and face validity. At the implementation stage, the data collection tool was a comprehension test on the IMFs concept.

\section{Content validity}

Content Validity contained four aspects that were assessed, including aspects of physical appearance, linguistics, concepts or content and writing approach. On the physical aspect, the validator assessed the format consistency, clarity of writing and the appropriateness of the image. In the linguistic aspect, the validator assessed the language styles that were interactive, unambiguous and easy to understand. In the concept or content aspect, the validator assessed the truth, depth, sequence and renewal of the presented concepts. In the writing approach aspect, the validator assessed the appropriateness of the material and learning objectives, the material's relevancy to daily life and association with macroscopic, microscopic and symbolic aspects. The scale conducted in the assessment ranged from 1-4 with scores 1, 2, 3 and 4 being irrelevant, less relevant, relevant and highly relevant respectively.

\section{Face validity}

Face Validity contains an assessment of the e-book on aspects of writing that was easy to read, explanations of the material were easy to understand, easy to use, images were appropriate with the contents of the material, videos were easy to understand and the material related to the daily lives of students who have learned the IMFs concept. The students assessed the e-book by giving an approval or disapproval on each item.

\section{Comprehension test on IMFs concept}

The comprehension test on IMFs concept contained the conceptual questions that were related to the learning objectives to be achieved after using the developed e-books in the learning process. The answers given by students were adjusted to the assessment rubric. 
The range of rubric was $1-5$. Students get a score of five if they had a firm command of basic concepts, a score of four if he or she showed nearly complete understanding of basic concepts, a score of three only had a tentative grasp of concepts, a score of two lacked command of most of the important concepts and a score of one showed no understanding of basic concepts or did not provide answers (Kubiszyn \& Borich, 2003).

\section{Analysis Data Technique}

The conducted data from content validity results were then determined by the value of the Validation Content Index (VCI) of each item assessed by dividing the number of validators who provided the relevant statements (scores 3 and 4) divided by the total number of validators. E-books were valid if they obtained a minimum CVI score of 0.8 (Wai Lam et al., 2018; Lau Chuan et al., 2019). The conducted data from the Face Validity results determined the percentage of approval of each item by dividing the number of students who gave approval divided by the total number of students involved in the Face Validity test.

Data from the implementation stage was determined by the mean score of students from the tested learning achievement indicator. Moreover, the classification of concepts of each item was conducted by the categories of understanding, almost understanding, merely understanding, less understanding and no understanding. The length of the category range (p) was determined by reducing the maximum score of each item i.e. the minimum score divided by the number of categories and the $\mathrm{p}$-value was 0.8 . The average category $(\mathrm{X})$ for each item can be seen in Table 1.

Table 1

Average Range Category of Student Understanding Concepts

\begin{tabular}{lll}
\hline No & Average Range & Category \\
\hline 1 & $1,0 \leq \mathrm{X} \leq 1,8$ & No understanding of the concept \\
2 & $1,8<\mathrm{X} \leq 2,6$ & Less understanding of the concept \\
3 & $2,6<\mathrm{X} \leq 3,4$ & Mere understanding of the concept \\
4 & $3,4<\mathrm{X} \leq 4,2$ & Almost understanding the concept \\
5 & $4,2<\mathrm{X} \leq 5,0$ & Full understanding of the concept \\
\hline
\end{tabular}

\section{FINDINGS}

\section{Analyze}

This stage was conducted by analysing the potential problems faced by prospective Chemistry teachers in understanding the IMFs concepts. The preliminary study that was conducted on third-year students in the Chemistry Education Study Program, the Faculty of Teacher Training and Education and Tanjungpura University found that they had difficulty in describing IMFs processes that occurred in the same or different compounds. The difficulty was caused by the limited information they obtained, both from the lecture materials and available textbooks. Based on the results of the preliminary study, teaching material that could facilitate the communication between students and teachers in describing the process of IMFs was needed. This is necessary because IMFs is a basic concept that provides the foundation in learning other concepts, especially in organic chemistry, such as the principle of "like dissolved like" or the solubility of organic compounds and predicting boiling and freezing points observed from the strength of IMFs. 


\section{Design}

The first step in the design stage was to determine the general learning outcomes related to IMFs concepts, content analysis or material needed in learning IMFs concepts and indicators of the learning outcomes (Table 2). Based on these results, it was found that learning IMFs concepts required prerequisite material such as the nature of macroscopic and material microscopic, ionic compounds and polarity of covalent molecules. This is related to Rompayom et al. (2011) who found that students had difficulty in solving IMFs concept problems because of the lack of comprehension of differences in IMFs (chemical bonds), the polarity of covalent compounds and the ability of ionic compounds to form ions if dissolved in solvents.

Table 2

The Relationship of Learning Achievements, Inter Molecular Style Concepts and Achievement Indicators

\begin{tabular}{|c|c|c|}
\hline $\begin{array}{l}\text { Learning } \\
\text { Outcome }\end{array}$ & Concept Analysis & Achievement Indicators \\
\hline \multirow[t]{3}{*}{$\begin{array}{l}\text { Describe } \\
\text { the process } \\
\text { of the } \\
\text { occurrence } \\
\text { of IMFs } \\
\text { between } \\
\text { similar and } \\
\text { different } \\
\text { molecules. }\end{array}$} & $\begin{array}{l}\text { 1. The material form } \\
\text { and constituent } \\
\text { particles including } \\
\text { the nature of } \\
\text { macroscopic and } \\
\text { material } \\
\text { microscopic. }\end{array}$ & $\begin{array}{l}\text { - Comparing the strength of forces between particles of solid, liquid and } \\
\text { gas. } \\
\text { - Describing solid, liquid or gas forms macroscopically. } \\
\text { - Explaining microscopically about the difference in density, shape in a } \\
\text { container, compressibility or thermal expansion of solid, liquid and gas } \\
\text { forms. } \\
\text { - Explain the difference in kinetic energy and attractive forces between } \\
\text { particles for solid, liquid and gas forms. }\end{array}$ \\
\hline & $\begin{array}{l}\text { 2. Molecules and its } \\
\text { classifications: } \\
\text { a. Ionic Compounds } \\
\text { b. Polar and Nonpolar } \\
\text { Covalent } \\
\text { Compounds }\end{array}$ & $\begin{array}{l}\text { - Differentiate ionic and covalent compounds based on the chemical } \\
\text { formula of a molecule. } \\
\text { - Determine the polarity of a covalent molecule based on its structural } \\
\text { formula. } \\
\text { - Predict the direction of movement of covalent molecules in liquid form } \\
\text { when brought near a charged field. }\end{array}$ \\
\hline & $\begin{array}{l}\text { 3. Intermolecular } \\
\quad \text { forces consists of: } \\
\text { a. London Force } \\
\text { b. Dipole-Dipole Force } \\
\text { c. Hydrogen Bonds } \\
\text { d. Ion-Dipole Force } \\
\text { e. Induced Ion/Dipole- } \\
\quad \text { Dipole Force }\end{array}$ & $\begin{array}{l}\text { - Describe the process of the London Force or dispersion between } \\
\text { nonpolar molecules. } \\
\text { - Describe the process of dipole-dipole force between polar molecules. } \\
\text { - Describe the process of hydrogen bonding between molecules that are } \\
\text { similar or different. } \\
\text { - Describe the process of ion-dipole force between ions and polar } \\
\text { molecules. } \\
\text { - Describe the process of inter-ion or dipole forces with nonpolar } \\
\text { molecules. }\end{array}$ \\
\hline
\end{tabular}

\section{Develop}

The next stage was development which included developing and validating the developed e-book. The development of a draft of the e-book utilized a multirepresentation approach by presenting macroscopic, microscopic and symbolic aspects in appropriate portions. The draft e-book started with the guide consisting of the preface, brief description, relevancy and learning outcomes of each chapter, introduction to multi-representation aspects, the relationship between the studied chemical concepts with the environment and health along with the format of sample problems accompanied by systematic completion steps (Figure 1). Providing a guide in using the e-book gave the reader knowledge about what they would encounter in the concept discussion of each chapter in the e-book. 

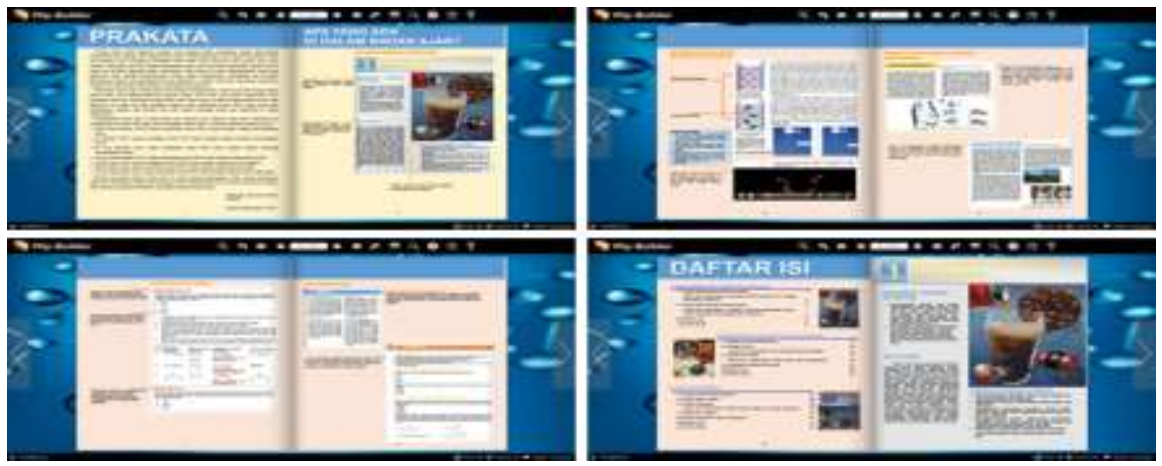

Figure 1

Preliminaries Consisting of Preface, Instructions in Using the E-Book and the Table of Contents

The explanation in the e-book provided a macroscopic, microscopic and symbolic description to help the reader comprehend the studied concepts. Related images were given in the macroscopic aspect, while the video was added in the microscopic aspect to ease the readers' comprehension of the conveyed explanation. The symbolic aspect was made as easy as possible through an explanation of a basic theory, for example, determination of the polarity of the covalent molecule was symbolised as a man being pulled by a rope and the difference in electronegativity was symbolised by the force of attraction (Figure 2).
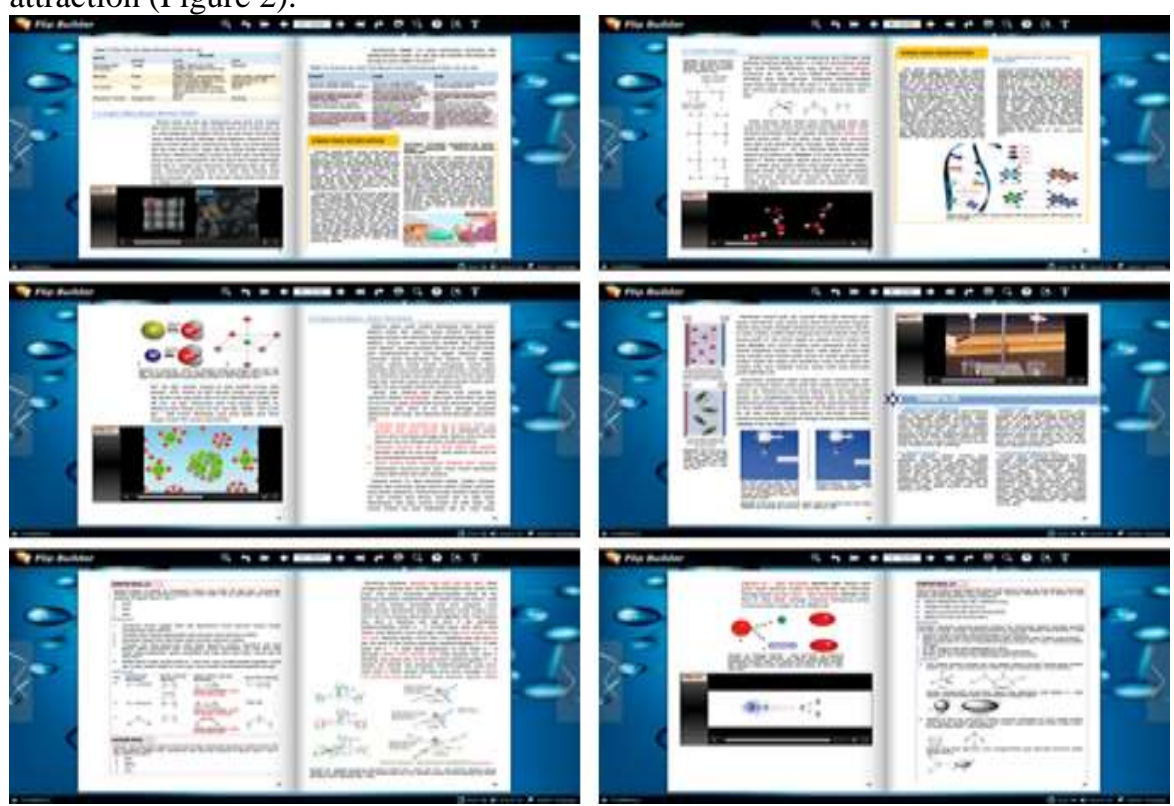

Figure 2

Contents in Multi-Representation based E-Book 
After the e-book draft had been developed, the next step was to get it validated by an expert. The results of content validity (Table 3) got an average CVI value of 0.95 and hence, it was valid. From these results, all validators stated that it had clarity in terms of writing; the language used was clear and it did not lead to ambiguous and double meanings. Furthermore, the concepts presented in the e-book were correct and had depth and was appropriate for the tertiary level. It was further observed that starting from the prerequisite concept, the presented concepts were sequential and some examples or illustrations were given based on relativeness to daily life.

Table 3

Content Validity Index of E-Book based on Multi-Representation by Validator $(n=7)$

\begin{tabular}{|c|c|c|c|c|c|}
\hline Aspect & Description & $\begin{array}{l}\text { Relevant (score } \\
3 \text { and } 4 \text { ) }\end{array}$ & $\begin{array}{l}\text { Not relevant } \\
\text { (score } 2 \text { and } 1)\end{array}$ & CVI & Category \\
\hline Physical & Format consistency & 7 & 0 & 1,00 & Valid \\
\hline \multirow[t]{2}{*}{ Appearance } & Writing & 6 & 1 & 0,86 & Valid \\
\hline & Image suitability & 7 & 0 & 1,00 & Valid \\
\hline \multirow[t]{3}{*}{ Linguistic } & Interactive & 6 & 1 & 0,86 & Valid \\
\hline & Unambiguous & 7 & 0 & 1,00 & Valid \\
\hline & Easy to understand & 6 & 1 & 0,86 & Valid \\
\hline \multirow[t]{4}{*}{ Concepts } & Concept truth & 7 & 0 & 1,00 & Valid \\
\hline & Concept depth & 7 & 0 & 1,00 & Valid \\
\hline & Order of concept & 7 & 0 & 1,00 & Valid \\
\hline & Renewal & 6 & 1 & 0,86 & Valid \\
\hline \multirow[t]{3}{*}{$\begin{array}{l}\text { Writing } \\
\text { approach }\end{array}$} & $\begin{array}{l}\text { Material suitability with } \\
\text { learning outcomes }\end{array}$ & 7 & 0 & 1,00 & Valid \\
\hline & $\begin{array}{l}\text { Relevant to everyday } \\
\text { reality }\end{array}$ & 7 & 0 & 1,00 & Valid \\
\hline & $\begin{array}{l}\text { Relations of macro, micro } \\
\text { and symbolic aspects in } \\
\text { the explanation }\end{array}$ & 6 & 1 & 0,86 & Valid \\
\hline Average & & & & 0,95 & Valid \\
\hline
\end{tabular}

Face validity was determined by involving 30 third-year students from the Chemistry Education Study Program, the Faculty of Teacher Training and Education and Tanjungpura University who have studied the IMFs. The results of Face Validity (Figure 3) noted that the level of approval had a score from $80 \%$ to $100 \%$ for each aspect. Based on these results, it could be concluded that the developed e-book could be accepted by students for their use in learning the IMFs concept.

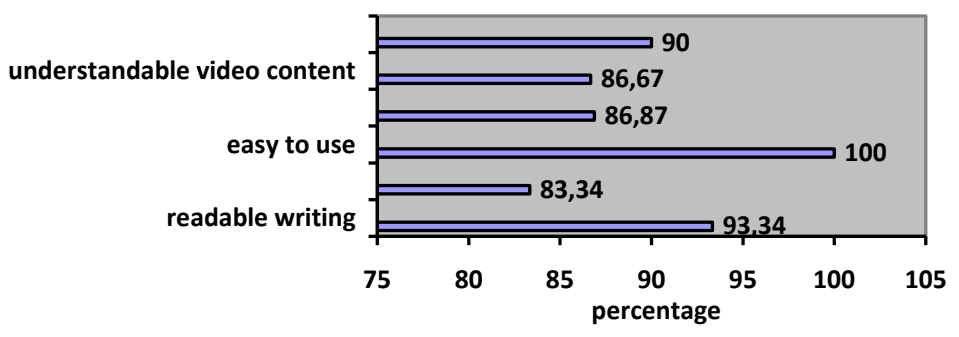

Figure 3

Correspondents' Approval Level at Face Validity 


\section{Implementation}

The use of the product was conducted in two meetings. Before the learning process began, students were asked to read the product that has been developed and summarised it into presentation slides. A week later, the first meeting started and students were asked to present their summary. The presentation was conducted in three parts. The first part was to present the concept of material form and its constituents. The second part was to present molecules classification into ionic compounds, polar and nonpolar covalent molecules. The third part was to present the IMFs concept. The time allocation in the first, second and third parts were 30 minutes, 60 minutes and 60 minutes respectively. The students who were to present for each section were selected by a lottery draw. At the second meeting, students were asked conceptual questions that were related to the learning outcomes and were asked to answer these questions by using the developed product.

The results in Table 4 below shows that the mean score of all items was in the understanding category. Based on the results, it indicated that the students could solve conceptual questions. Thus, it can be concluded that the developed e-book could help students learn independently and assist them in understanding the contents of the presented material in the e-book.

Table 4

Student Achievement Value in Working on Learning Outcomes Questions for the Developed Product

\begin{tabular}{llll}
\hline No & Learning Outcomes & $\begin{array}{l}\text { Average } \\
\text { Score }\end{array}$ & Category \\
\hline 1 & $\begin{array}{l}\text { Compare the strength of forces between particles in solid, liquid and } \\
\text { gas forms. }\end{array}$ & 4,63 & Understand \\
\hline 2 & Explain the form of solid, liquid or gas macroscopically. & 4,71 & Understand \\
\hline 3 & $\begin{array}{l}\text { Explain the difference in density, shape in a container, compressibility } \\
\text { or thermal expansion of solid, liquid and gas forms microscopically. }\end{array}$ & 4,32 & Understand \\
\hline 4 & $\begin{array}{l}\text { Explain differences in kinetic energy and attractive forces between } \\
\text { particles for solid, liquid and gas forms. }\end{array}$ & 4,61 & Understand \\
\hline 5 & $\begin{array}{l}\text { Differentiate ionic and covalent compounds based on the chemical } \\
\text { formula of a molecule. }\end{array}$ & 4,81 & Understand \\
\hline 6 & $\begin{array}{l}\text { Determine the polarity of a covalent molecule based on its structural } \\
\text { formula. }\end{array}$ & 4,42 & Understand \\
\hline 7 & $\begin{array}{l}\text { Predict the movement direction of covalent molecules in liquid form } \\
\text { when brought near a charged field. }\end{array}$ & 4,42 & Understand \\
\hline 8 & $\begin{array}{l}\text { Describe the process of London Force or dispersion between nonpolar } \\
\text { molecules. }\end{array}$ & 4,14 & Almost \\
\hline 9 & $\begin{array}{l}\text { Describe the process of occurrence of dipole-dipole forces between } \\
\text { polar molecules. }\end{array}$ & 4,62 & Understand \\
\hline 10 & $\begin{array}{l}\text { Describe the process of hydrogen bonding between molecules that are } \\
\text { similar or different. }\end{array}$ & 4,32 & Understand \\
\hline 11 & $\begin{array}{l}\text { Describe the process of ion-dipole forces between ions and polar } \\
\text { molecules. }\end{array}$ & 4,56 & Understand \\
\hline 12 & $\begin{array}{l}\text { Describes the process of force of ion/dipole and nonpolar molecules. } \\
\text { Average }\end{array}$ & 4.16 & $\begin{array}{l}\text { Almost } \\
\text { Understand }\end{array}$ \\
\hline & \begin{tabular}{l} 
Understand \\
\hline
\end{tabular}
\end{tabular}




\section{Evaluation}

This stage was conducted to evaluate the results obtained at the implementation stage and flaws that were corrected in the developed e-book. Based on the results from the implementation stage, two learning outcomes had not shown the expected results. These outcomes were describing the process of London Force and the occurrence of forces between ions or dipoles with nonpolar molecules. From the answers obtained by the students, it showed that the students were still having difficulty comprehending the process of forming induced dipole from nonpolar molecules. Therefore, there were some small revisions done in the e-book by adding pictures that made it easier for students to comprehend the process of forming induced dipoles from nonpolar molecules.

After the small revisions, the developed e-book was distributed to the Chemistry students through a Google Drive link (http://bit.ly/Gaya_Antar_Molekul) and could be downloaded for free by the students.

\section{DISCUSSION}

This study aims to find out the level of students achievement when using multimedia The purpose of this research was to produce a multi-representation based e-book on intermolecular forces that was valid and suitable for use. In this study, the validity of ebooks was seen from the construct validity and face validity. The construct validation is intended to assess the accuracy of the e-book and get feedback from the appropriate experts (Ahmad et al., 2011; Setambah et al., 2017). Based on Table 3, it is known that the e-book developed was valid. These results illustrate that the e-book used clear language (in Indonesian), did not give the user multiple meanings and made it easier for students to understand the content conveyed in the e-book. In addition, the concepts presented by e-books were correct, sequential, contained current values and was up to the tertiary level. The most important outcome from the e-book was that the student could link macroscopic, microscopic and symbolic aspects in conveying the concept of IMFs. The macroscopic aspects in e-books related to phenomena that appear in everyday life which are related to the concept of IMFs such as the solid, liquid and gas forms of a substance. The symbolic aspect in the e-book was presented with images accompanied by an explanation in words. For example, writing molecular formulas and determining the polarity of a molecule. Microscopic aspects in the e-book were presented through dynamic visualisation in the form of videos that made it easier for students to understand the process of forming forces between particles, including the London Force, dipoles, hydrogen bonds, ion-dipoles and ionised/dipole with induceddipole.

Face Validity in this study was used to analyse the responses of prospective e-book users and observe whether there was a gap between expert judgment and prospective users (Goel et al., 2012). Figure 3 shows that potential users showed a high level of interest in the e-book that was developed. The high interest in e-books can help them learn independently so that it has an impact on the quality of their learning (Paolini, 2015; Cheng, 2016). Prospective users gave a very high interest in aspects such as relevancy with real life, ease of use and readable writing with a percentage equal to or 
higher than $90 \%$. Linking concepts with real life can motivate students to learn with the emergence of the notion that the concepts learned are important to master because they have a direct link in their lives (Tenaw, 2015). High interest was also shown by potential users in the understandable aspects of video content, image appropriateness and concept explanation with a percentage above $80 \%$. This illustrates that the conceptual explanation of e-books visually in the form of videos and pictures can help students obtain complete information compared to just explanations in text form (Bobek \& Tversky, 2016).

The results of implementing e-books in the learning process showed that students could understand the concept of IMFs (illustrated in Table 4). The results obtained illustrated that the e-book developed made it easier for students to learn and grasps the concepts easily. The reasons for such were the concept of the IMFs in the e-book was presented in clear and unambiguous language, the compatibility between the pictures and explanations, the concepts were presented correctly and the direct relation to daily life. On the microscopic aspect, e-books present dynamic visualisation in the form of videos that relate to the concept of the IMFs, especially for indicators describing the process of the London Force, dipole-dipole, hydrogen bonds, ion-dipole and ion / dipole-dipoleinduced. Measurements after learning by using an e-book for the indicators described the process of the London Force, dipoles, hydrogen bonds, ion-dipole and ion / dipoledipole induced were in the category of almost understanding, understanding, comprehending, understanding and almost understand respectively. Thus, it can be said that the provision of moving visualisations in the form of videos made it easier for students to understand the concept of IMFs, especially in the microscopic aspect. Several other studies have shown that providing dynamic visualisation can assist students understand concepts taught microscopically. Barbosa et al. (2015) found that the provision of dynamic visualisation in the form of IMF concept animation software contributed to the formation of concepts by student which was seen from an increase in scores during diagnostic tests and final tests by $65.2 \%$. Venkataraman, B (2009) showed that providing interactive visualisation at the molecular level can help students explain the chemical phenomenon at the molecular level marked through the results of an average final score of 84 . Thus, the e-book developed was feasible for use because it was proven to make students understand the concept of IMFs better when applied in the learning process.

\section{CONCLUSION}

The e-book developed is valid and appropriate for use in the learning process. It can facilitate students in learning the concepts of intermolecular forces. The validity of ebooks is concluded from the results of content validation and face validity. The results of content validation (Content Validity) in this study obtained a VCI value of 0.95 and was hence, categorised as valid. The results of the Face Validity for the e-book was that the writing style was easy to read, the explanation of the material and the videos were easy to understand and comprehend and the images were corresponding to the contents. Overall, the e-book was easy to understand by the user and the material was satisfactorily associated with daily life with the percentages in a row being $93.34 \%$, 
$83.34 \%, 100 \%, 86.67 \%, 86.67 \%$ and $90 \%$. The e-book was found to be appropriate if the implementation phase can help the students understand the concept of IMFs. The results of this study for the implementation of e-books in learning process was that the use of the e-book obtained learning outcomes and was mastered by students with an overall average score of 4.50 . Hence, the e-book developed was suitable for use in the learning process.

\section{SUGGESTIONS}

At the development stage, validation was the determining aspect of whether the developed e-book can be implemented in the learning process. Validation involves two forms, namely content validation and face validity. In order for the validation activities to work well, a Focus Group Discussion is strongly recommended for these activities. The goal is to create a common perception between researchers, experts as assessors of content validation and prospective users as assessors of face validity on the aspects to be measured. In addition, at the implementation stage, it is necessary to consider approaches, methods or models that are appropriate for the characteristics of students. Group discussions are strongly recommended in the use of this e-book. With group discussions, the students involved in the learning process can interact and exchange opinions about the concepts they learn.

\section{REFERENCES}

Ahmad, J., Amat, M. A. C., Yahaya, S. N., Tuyuf, R., \& Alias, S. R. (2011). The construction, validity, reliability and effectiveness of drug rehabilitation module on selfconcept of female addicts and motivation achievement of male addicts in Malaysia. International Journal of Humanities and Social Science, 1(10), 217-228.

Al-Balushi, S. M. (2013). The effect of different textual narrations on students' explanations at the submicroscopic level in chemistry. Eurasia Journal of Mathematics, Science \& Technology Education, 9(1), 3-10.

Aydin, S., Sinha, S., \& Izci, K. (2014). Turkish, Indian and American chemistry textbook use of insciptions to represent "types of chemical reactions". Eurasia Journal of Mathematics, Science \& Technology Education, 10(5), 383 - 393.

Barbosa, F. G., Mafelozi, J., Lima, M. A. S., Alexandre, F. S. O., Almeida, D. M., Junior, A. J. M. L., \& Junior, J. N. S. (2015). Interactions: Design, implementation and evaluation of a computational tool for teaching intermolecular forces in higher education. Quimica Nova, 38(10), 1351-1356.

Bhatti, Z. B., Abro, A. Gillal, A. R., \& Karbasi, M. (2017). Be-educated: Multimedia learning through $3 \mathrm{~d}$ animation. Int J of Computer Sci and Emerging Tech, 1(1), 13-22.

Biranvand, A., \& Khasseh, A. A. (2014). E-book reading and impact on academic status of students at Payame Noor University, Iran. Library Philosophy and Practice (eJournal), 1170, $1-12$. 
Bobek, E., \& Tversky, B. (2016). Creating visual explanations improves learning. Cognitive Research: Principles and Implications, 27(1), from https://doi.org/10.1186/s41235-016-0031-6.

Branch, R. M. (2009). Instructional design: The ADDIE approach. New York: Springer Science Business Media, LCC.

Cheng, G. (2016). An empirical study towards understanding user acceptance of bring your own device (BYOD) in higher education. Australian J of Edu Tech, 34(4), 1-17.

Cooper, M. M., Williams, L. C., \& Underwood, S. M. (2015). Student understanding of intermolecular forced: A multimodel study. J of Chemical Education, 92, 1288 - 1298.

Demirdogen, B. (2017). Examination of chemical representations in Turkish high school chemistry textbook. Journal of Baltic Science Education, 16(4), 472 - 499.

Ebied, M. M. A., \& Rahman, S. A. A. (2015). The effect of interactive e-book on students' achievement at Najran university in computer in education course. Journal of Education and Practice, 6(19), 71 - 82.

Gkitzia, V., Salta, K., \& Tzougraki, C. (2011). Development and application of suitable criteria for the evaluation of chemical representations in school textbooks. Chemistry Education Research and Practice, 12(1), 5 - 14.

Goel, L., Zhang, P., \& Templeton, M. (2012). Transactional distance revisited: Bridging face and empirical validity. Computers in Human Behavior, 28(4), 1122-1129.

Guzel, B. Y., \& Adadan, E. (2013). Use of multiple representations in developing preservice chemistry teachers' understanding of the structure of matter. International Journal of Environmental \& Science Education, 8(1), 109 - 130.

Harst, S., \& Savec, V. F. (2017). The integration of submicroscopic representations used in chemistry textbook sets into curriculum topics. Acta Chimi Slov 64(4), 956-967.

Hwang, I., Tam, M., Lam, S. L., \& Lam, P. (2012). Review of use of animation as a supplementary learning material of physiology content in four academic years. Electronic Journal of e-Learning, 10(4), 368 - 377.

Kubiszyn, T., \& Borich, G. (2003). Educational testing and measurement. John Wiley \& Sons

Kumar, B. S., Perumal, A., Kumar, C. M., \& Deepa, J. (2016). 3D animation as an effective learning tool. Int Res J of Engineering and Technology, 3(11), 397-399.

Lau Chuan, X., Long Wong, Y., Eiin Wong, J., Koh, D., Sedek, R., Jamil, A. T., Oon Ng, A. L., Hazizi, A. S., Ruzita, A. T., \& Koon Poh, B. (2019). Development and validation of a physical activity educational module for overweight and obese adolescent: CERGAS programe. Int J of Env Res and Pub Health, 16(9), 1506.

Lawrie, G., Wright, A., Schultz, M., Dargaville, T., O’Brien, G., Bedford, S., Williams, M., Tasker, R., Dickson, H., \& Thompson, C. (2013). Using formative feedback to 
identify and support first year chemistry students with missing or misconceptions. A practice report. The Int $J$ of the First Year in Higher Education, 4(2), 111-116.

Linda, R., Herdini, Sulistya, I., \& Putra, T. P. (2018). Interactive e-module develompment trough chemistry magazine on kvisoft flipbook maker application for chemistry learning in second semester at second grand senior high school. Journal of Science Learning, 2(1), $21-25$.

Malkoc, U. (2017). Investigating teachers' understanding of the salt dissolution process: A multi-media approach in education. The Turkish Onl J of Edu Tech, 16(1), 55 - 71.

Musawwa, M. M., Febriana, B. W., \& Arlianty, W. N. (2018). Analysis of understanding of firt-year chemistry education students on intermolecular forces (IMFs) topic. International Journal of Chemistry Education Research, 2(2), 71-76.

Pande, P., \& Chandrasekharan, S. (2017). Representational competence: Toward a distributed and embodied cognition account. Studies in Science Education, 53(1), 1-43.

Paolini, A. (2015). Enhancing teaching effectiveness and student learning outcomes. The Journal of Effective Teaching, 15(1), 20-23.

Parpageorgiou, P., Markos, A., \& Zarkadis, N. (2016). Understanding the atom and relevant misconceptions: students' profiles in relation to three cognitive variables. Science Education International, 27(4), 464 - 488.

Phillip, S. B., Jhonson, D. K., \& Yazierki, E. J. (2014). Development of protocol to evaluate the use of representations in secondary chemistry instruction. Chemistry Education Research and Practice, 15(4), 777 - 786.

Raihan, S., Haryono, \& Ahmadi, F. (2018). Development of scientific learning e-book using 3d pageflipp professional program. Innovative J of Curr \& Edu Tech, 7(1), 7-14.

Rantih, N. K., Mulyani, S., \& Widhiyanti, T. (2019). An analysis of multiple representation about intermolecular forced. Journal of Phys: Conf. Series, 1157042029.

Rompayom, P., Tambunchong, S. W., \& Dechri, P. (2011). Using open-ended question to diagnose students' understanding of inter-and intramolecular forced. "Proceeding International Conference by National Association for Research in Science Teaching, (12-23). Virginia, USA: David Publishing.

Rusli, M., \& Negara, K. R. (2017). The effect of animation in multimedia computerbased learning a learning style to the learning results. Turkish Online Journal of Distance Education (TODJE), 18(4), 177 - 190.

Scalco, K. C., Talanquer, V., Kiill, K. B., \& Cordeiro, M. R. (2018). Making sense of phenomena from sequential images versus illustrated text. J of Chemi Edu, 95, 347-354.

Schmidt, H. J., Kaufmann, B., \& Treagust, D. F. (2009). Students' understanding of boiling points and intermolecular forces. Chemistry Edu Res and Practice, 10, 219-226. 
Setambah, M. A. B., Tajudin, N. M., Adnan, M., \& Saad, M. I. M. (2017). Adventure based learning module: Content validity and reliability process. International Journal of Academic Research in Business and Social Sciences, 7(2), 615-623.

Siew Li, W. S., \& Arshad, M. Y. (2014). Wait-time and multirepresentation levels in chemistry lesson. The Malaysian Online Journal of Educational Science, 2(2), 45 - 53.

Skamp, K. (2009). Atoms and moleculer in primary science: What are teacher to do? Australian Journal of Education in Chemistry, 68, 5 - 10.

Sunyono, S., Efkar, T., \& Munifatullah, F. (2017). The influence of multiple representation strategies to improve the mental model of $10^{\text {th }}$ grade students on the concept of chemical bonding. The Turkish o- J of Desi, Art \& Comm: S. Ed, 1606-1614.

Sunyono. (2015). Introductory study on students mental models in understanding the concept of atomic structure (Case Study on High School Student in Lampung Indonesia). The Online Journal of New Horizons in Education, 5(4), 41 - 50.

Tasker, R., \& Dalton, R. (2006). Research into practice: Visualisation of the molecular word using animations. Chemistry Education Research and Practice, 7(2), 141 - 159

Tenaw, Y. A. (2015). Effective strategies for teaching chemistry. International Journal of Education Research and Reviews, 3(3), 78-84.

Venkataraman, B. (2009). Visualization and interactivity in the teaching of chemistry to science and non-science students. Chemistry Edu Research and Practice, 10, 62-69.

Wai Lam, K., Hassan, A., Sulaiman, T., \& Kamarudin, N. (2018). Evaluation the face and content validity of an instructional technology competency instrument for university lecturers in Malaysia. Int J of Acad Res in Business \& Soc Sci, 8(5), 362-385.

Widarti, H. Y., Marfuaf, S., \& Retnosari, R. (2019). Identifying students' misconception about intermolecular forced topics on organic chemistry I course. Unnes Science Education Journal, 8(1), 46-56.

Yasa, A. D., Chisyarani, D. D., Akbar, S., \& Mudiono, A. (2018). E-module based on ncesoft book maker for primary school student. Int J of Engi \& Tech, 7(3), 286-289.

Yayla, R. G \& Eyceyurt, G. (2011). Mental models of pre-service science teachers about basic concepts in chemistry. Western Anatolia J of Edu Science, 4, 285 - 294.

Zang, Z. H., \& Linn, M.C. (201)1. Can generating representations enhance learning with dynamic visualization? Journal of Research in Science Tech, 48(10), 1177-1198. 